\title{
Construction of influenza virosome from influenza A H1N1 PR8
}

\author{
Mehri Noori ${ }^{1 *}$, Shirin Ghorbani ${ }^{1}$, Abbas Jamali ${ }^{2}$, Mohammad Shenagari ${ }^{3}$, Hamidreza Hashemi ${ }^{3}$, \\ Masoumeh Tavassoti Kheiri ${ }^{2}$ \\ From Institut Pasteur International Network Annual Scientific Meeting \\ Hong Kong. 22-23 November 2010
}

Influenza is a major viral respiratory infection of humans, responsible for 300,000-500,000 annual deaths world-wide. The influenza viruses are competent of genetic variation, both by continuous, gradual mutation and by reassortment of genome segments between viruses. Antigenic drift is the gradual evolution of viral strains, due to frequent mutations of the surface glycoproteins hemagglutinin and neuraminidase. Novel and increasingly safer vaccines use well-characterized antigens. Conversely, these antigens are regularly too small to be highly immunogenic and would help from administration of a suitable adjuvant. The virosomes are reconstituted influenza virus envelopes devoid of central core and genetic in sequence. In this study we proposed to construct an influenza virosome structure from influenza A H1N1 PR8.

During the production process, MDCK cells were cultured then infected with influenza virus strain PR8 and finally the supernatant harvested and purified by ultracentrifugation and ultrafiltration. Purified influenza virus treated by DCPC as a detergent to resolve envelop of influenza virus. Then, RNP of influenza virus participated by using ultracentrifugation. The envelope of influenza virus was reconstituted by removing of DCPC by using overnight dialysis against HBS buffer. Finally, we observed empty influenza virus envelop by TEM, their called virosomes. The size of these particles was estimated between $50-150 \mathrm{~nm}$.

\section{Author details}

${ }^{1}$ Department of Biology, Alzahra University, Tehran, 1993891176, Iran. ${ }^{2}$ Department of Virology (Influenza Unit), Pasteur Institute of Iran, Tehran,

1316943551, Iran. ${ }^{3}$ Guilan University of Medical Science, Guilan, Iran.

'Department of Biology, Alzahra University, Tehran, 1993891176, Iran

Full list of author information is available at the end of the article
Published: 10 January 2011

doi:10.1186/1753-6561-5-S1-P5

Cite this article as: Noori et al:: Construction of influenza virosome from influenza A H1N1 PR8. BMC Proceedings 2011 5(Suppl 1):P5.
Submit your next manuscript to BioMed Central and take full advantage of:

- Convenient online submission

- Thorough peer review

- No space constraints or color figure charges

- Immediate publication on acceptance

- Inclusion in PubMed, CAS, Scopus and Google Scholar

- Research which is freely available for redistribution
() Biomed Central
C Biomed Central

(c) 2011 Noori et al; licensee BioMed Central Ltd. This is an open access article distributed under the terms of the Creative Commons Attribution License (http://creativecommons.org/licenses/by/2.0), which permits unrestricted use, distribution, and reproduction in any medium, provided the original work is properly cited. 